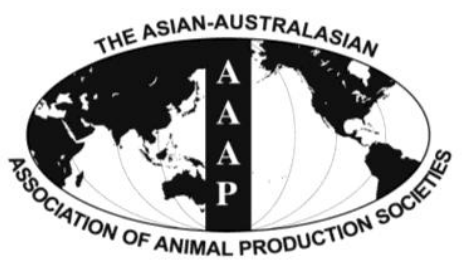

Asian Australas. J. Anim. Sci.

Vol. 26, No. 11 : 1651-1658 November 2013

http://dx.doi.org/10.5713/ajas.2013.13184

www.ajas.info

pISSN 1011-2367 elSSN 1976-5517

\title{
Isolation and Characterization of Novel Denitrifying Bacterium Geobacillus sp. SG-01 Strain from Wood Chips Composted with Swine Manure
}

\author{
Seung-Hak Yang, Jin-Kook Cho ${ }^{1}$, Soon-Youl Lee ${ }^{2}$, Oliver D. Abanto ${ }^{3}$, Soo-Ki Kim ${ }^{4}$, \\ Chiranjit Ghosh, Joung-Soo Lim, and Seong-Gu Hwang ${ }^{1, *}$ \\ Animal Environment Division, National Institute of Animal Science, R. D. A. Gyeonggi 441-706, Korea
}

\begin{abstract}
Nitrate contamination in ground and surface water is an increasingly serious environmental problem and only a few bacterial strains have been identified that have the ability to remove nitrogen pollutants from wastewater under thermophilic conditions. We therefore isolated thermophilic facultative bacterial strains from wood chips that had been composted with swine manure under aerated high temperature conditions so as to identify strains with denitrifying ability. Nine different colonies were screened and 3 long rod-shaped bacterial strains designated as SG-01, SG-02, and SG-03 were selected. The strain SG-01 could be differentiated from SG-02 and SG-03 on the basis of the method that it used for sugar utilization. The 16S rRNA genes of this strain also had high sequence similarity with Geobacillus thermodenitrificans $465^{\mathrm{T}}(99.6 \%)$. The optimal growth temperatures $\left(55^{\circ} \mathrm{C}\right), \mathrm{pH}$ values $(\mathrm{pH} 7.0)$, and $\mathrm{NaCl}$ concentrations $(1 \%)$ required for the growth of strain SG-01 were established. This strain reduced $1.18 \mathrm{mM}$ nitrate and $1.45 \mathrm{mM}$ nitrite in LB broth after $48 \mathrm{~h}$ of incubation. These results suggest that the G. thermodenitrificans SG-01 strain may be useful in the removal of nitrates and nitrites from wastewater generated as a result of livestock farming. (Key Words: Compost, Denitrification, Geobacillus thermodenitrificans, Nitrates, Nitrites, Swine Manure, Wood Chips)
\end{abstract}

\section{INTRODUCTION}

Nitrogen compounds released by industrial and domestic activities have been increasingly accumulating in lakes, wetlands, and enclosed areas of the sea (Zhou et al., 2007). In particular, full-scale swine waste treatment systems generate wastewater containing nitrogen compounds that cause environmental pollution. Wood chips are commonly used in swine wastewater treatments in order to alleviate noxious odors and decrease water pollution (de Guardia et al., 2008). Previous studies have examined wood

\footnotetext{
* Corresponding Author: Seong-Gu Hwang. Tel: +82-31-6705121, Fax: +82-31-670-5127, E-mail: sghwang@hknu.ac.kr

${ }^{1}$ Division of Animal Life and Environmental Science, Hankyong National University, Anseong-si, Gyeonggi-do 450-749, Korea.

${ }^{2}$ School of Genomic Engineering, Hankyong National University, Anseong-si, Gyeonggi-do 450-749, Korea.

3 Animal and Dairy Sciences Cluster, University of the Philippines Los Baños, College, Laguna 4031, Philippines.

4 Department of Animal Science and Technology, Konkuk University, Seoul 143-701, Korea.

Submitted Apr. 3, 2013; Accepted Jun. 4, 2013; Revised Jul. 5, 2013
}

compost production from bark, sawdust, and wood shavings (McGowin et al., 2001; Zoes et al., 2001; Horiuchi et al., 2003) however, only a few reports have evaluated composting methods using wood chips (Tiquia and Tam, 2000).

The composting process results in biodegradationinduced metabolic heat production that can increase temperatures above $70^{\circ} \mathrm{C}$. Only a few specialized microbes can live under these extreme environmental conditions, and the activity and diversity of composting bacterial strains are greatly suppressed at compost temperatures greater than $60^{\circ} \mathrm{C}$. Strains related to Bacillus stearothermophilus usually dominate under these conditions (Suler and Finstein, 1977; Strom, 1985). Recently, 34 thermophilic bacterial species (grown at $60^{\circ} \mathrm{C}$ ) were isolated during aerobic composting of poultry and cattle manure (Wang et al., 2007), and Geobacillus thermodenitrificans was one of those species.

It has been reported that the chemical oxygen demand, sewage sludge, total nitrogen content, and total phosphorous content of swine manure were reduced by passing through filtering system using wood chips (Choi et al., 2008; Gilbert et al., 2008). 
However, the mechanisms involved in reducing the nitrogen compounds have not been identified. Some microorganisms have been associated with the denitrification process, which eliminates fixed nitrogen from the environment and removes excess nitrates during wastewater treatment. Certain bacteria, such as Pseudomonas stutzeri, participate in the denitrification process by using nitrate or nitrite as the ultimate electron acceptor for anaerobic respiration (Cheneby et al., 2004; Philippot, 2005b). Biological denitrification is considered one of the most effective processes for removing nitrogen pollutants from wastewater. It is therefore worthwhile to isolate and characterize microorganisms that utilize nitrogen compounds from swine manure composted in wood chips.

In the present study, a thermophilic bacterial strain, SG01, was isolated from wood chips composted with swine manure and identified. Studies were then performed to determine the optimal temperature, $\mathrm{pH}$ and $\mathrm{NaCl}$ concentrations for growth of the strain. Finally nitrogen reduction assays were also performed in order to measure nitrogen utilization by the SG-01 strain.

\section{MATERIALS AND METHODS}

\section{Swine manure composting system}

Swine manure was obtained from a swine farm in Kimpo, Korea. Sludge was removed from the swine manure, and liquid waste was sprayed into the filtering system made up of thinning-out tree wood chips piled in a container (10 $\mathrm{m}$ width $\times 10 \mathrm{~m}$ length $\times 6 \mathrm{~m}$ height). The wood chips were used to pack the filter, which was then utilized in the microbial-degradation phase of the composting. The filtering system was spontaneously self-heated in aerobic condition and kept at approximately $60^{\circ} \mathrm{C}$ for several days. Wood chip temperatures reached a peak of $66^{\circ} \mathrm{C}$ during the second week of composting and were maintained at that level until d 21 for the thermophilic stage of composting. The average temperature of the filtering system during this process was $60.7^{\circ} \mathrm{C}$. Temperatures in the composting piles decreased gradually after the thermophilic stage until they reached ambient temperatures of approximately 27 to $30^{\circ} \mathrm{C}$. The $\mathrm{pH}$ of the final wood chip compost was 8.3.

\section{Isolation and growth of bacteria from the wood chips}

Composted wood chips $(1 \mathrm{~g})$ were mixed with $5 \mathrm{~mL} \mathrm{LB}$ media, stirred for $5 \mathrm{~min}$, and incubated at room temperature for $30 \mathrm{~min}$. Sample supernatants $(100 \mu \mathrm{L})$ were plated on $1.5 \% \mathrm{LB}$ agar plates and incubated at $55^{\circ} \mathrm{C}$ for $24 \mathrm{~h}$ in a sealed humidified jar to prevent plate drying. Three strains were selected for further investigation based on the colony color, odor, and morphological features.

\section{Bacterial identification}

The bacteria were identified by 16S rRNA sequence homology analysis as follows. Genomic DNA was isolated from these strains and used for the amplification of the $16 \mathrm{~S}$ rRNA gene fragment as previously described (Sogin, 1990). Briefly, 16S rRNA gene fragment was amplified by the polymerase chain reaction (PCR) using the eubacterial universal primers 27F (5'-AGAGTTTGATCCTGGC TCAG-3') and 1492R (5'-GGTTACCTTGTTACGACTT3'). Polymerase chain reaction (PCR) were performed using a thermal cycler (Takara Bio Inc. Japan) with an initial denaturation step of $94^{\circ} \mathrm{C}$ for $3 \mathrm{~min}$, followed by 35 amplification cycles consisting of denaturation at $94^{\circ} \mathrm{C}$ for $60 \mathrm{~s}$, annealing at $60^{\circ} \mathrm{C}$ for $60 \mathrm{~s}$, and elongation at $72^{\circ} \mathrm{C}$ for 60 s. The reaction was terminated with a terminal elongation step of $72^{\circ} \mathrm{C}$ for 3 min followed by cooling at $4^{\circ} \mathrm{C}$. The resulting PCR band was used for nucleotide sequence analysis. Nucleotide sequences of approximately $1,450 \mathrm{bp}$ length were analyzed for similarity to the $16 \mathrm{~S}$ rRNA sequence of the isolated bacteria by using the BLAST program (Altschul et al., 1997). The nucleotide sequences of 16S rRNA were analyzed three times for each strains and aligned using the ClustalW program for multiple sequence alignment (Thompson et al., 1994). The evolution distance matrix was calculated using the Kimura 2parameter evolution model (Kimura, 1983). The resulting phylogenetic tree was constructed using neighbor-joining analysis (Saitou and Nei, 1987; Felsenstein, 1993). Biochemical identification was also performed using API 50CHB (BioMerieux, Hazelwood, MO) according to the manufacturer's instructions.

\section{Physiological characterization}

The optimum $\mathrm{NaCl}$ concentration for bacterial growth was determined using previously described methods (DeFlaun et al., 2007). The effect of temperature on growth was tested in LB broth. An additional study was performed to determine the optimal $\mathrm{pH}$ for growth in a buffered system. The $\mathrm{LB}$ broth was adjusted to $\mathrm{pH}$ values ranging from 5.0 to 9.5 (room temperature) by using the following buffers: $50 \mathrm{mM}$ citrate- $\mathrm{Na}_{2} \mathrm{HPO}_{4}$ buffer ( $\mathrm{pH} 5.0$ to 6.8 ), $50 \mathrm{mM}$ Tris$\mathrm{HCl}$ buffer (pH 7.0 to 8.0 ), and $50 \mathrm{mM}$ glycine- $\mathrm{NaOH}$ buffer ( $\mathrm{pH} 8.5$ to 9.5 ). Each LB broth was inoculated with an SG-01 culture that had been grown overnight. Optical density at $600 \mathrm{~nm}$ was analyzed by measuring absorbance values every $6 \mathrm{~h}$. The initial optical density of each culture was 0.04. The Specific growth rate is defined as the increase in cell mass per unit time, e.g., grams cells (g) per gram cells (g) per hour: $\left(\mathrm{g} \cdot \mathrm{g}^{-1} \cdot \mathrm{h}^{-1}\right)$.

\section{Nitrate and nitrite reduction assays}

A jar fermenter was used to investigate the SG-01 growth curve and to perform nitrate and nitrite reduction 
assays. The $\mathrm{pH}$ changes were also monitored during this process. Bacterial cells $(1 \%)$ were inoculated into $100 \mathrm{~mL}$ LB broth containing $2.0 \% \mathrm{NaCl}$ and supplemented with 100 ppm nitrate $\left(1.18 \mathrm{mM} \mathrm{NaNO}_{3}\right)$ or nitrite $\left(1.45 \mathrm{mM} \mathrm{NaNO}_{2}\right)$, and then incubated at $55^{\circ} \mathrm{C}$ for $48 \mathrm{~h}$. The modified brucinesulfanilic acid method (APHA, 1989) was used to measure nitrate concentrations. Nitrite concentrations were measured using the Griess reaction (Green et al., 1982) Color absorbance was measured at $540 \mathrm{~nm}$ by using a spectrophotometer (U-2000, Hitachi, Japan). Un-inoculated samples were used as controls for the nitrate and nitrite reduction assays. Experiments were performed in triplicate, and standard curves were generated for each experiment by using known concentrations of sodium nitrate and sodium nitrite as references.

\section{RESULTS}

\section{Identification and characterization of the isolated bacteria}

Nine different colonies from the samples of the wood chips composted with swine manure were isolated and grouped based on colony morphological characteristics, color, and odor. Biochemical characteristics were analyzed in 3 rod-shaped spore-forming candidate bacteria, SG-01, SG-02, and SG-03.

The PCR products for 16S rRNA (approximately 1,450 bp) were isolated and sequenced. Sequence homology analysis revealed that SG-01 had 98 to $99 \%$ homology with the Geobacillus genus. However, the sequences of the 3 strains were not-identical and the strain SG-01 was phylogenetically related to Geobacillus thermodenitrificans species (99\% similarity with $16 \mathrm{~S}$ rRNA of the strain $465^{\mathrm{T}}$ ). The phylogenetic position of the studied strains among

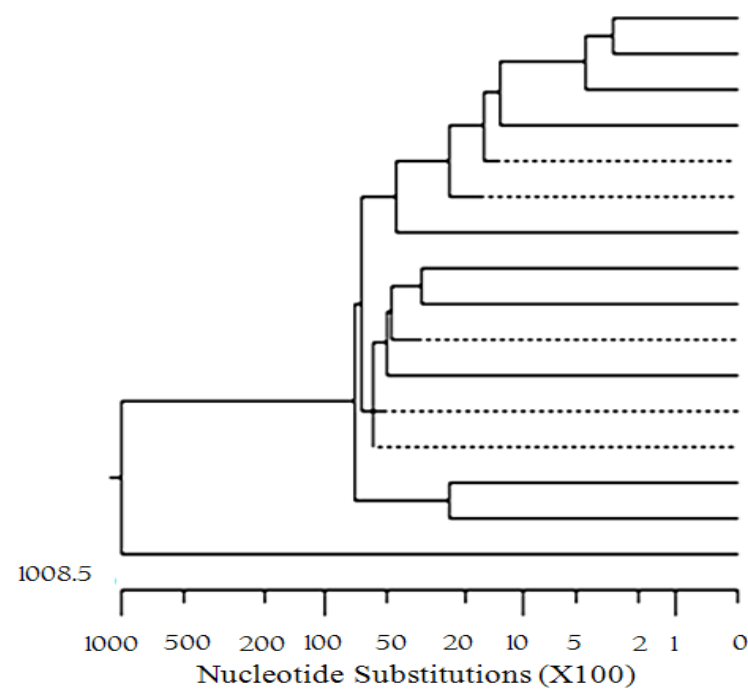

other Geobacillus species is shown in Figure 1.

The results of biochemical analyses using the API $50 \mathrm{CHB}$ kit revealed that the SG-01, SG-02, and SG-03 strains were biochemically unique based on the utilization of L-arabinose, fructose, inositol, melibiose, sucrose, raffinose, and glycogen (Table 1). The SG-02 and SG-03 strains used L-arabinose, melibiose, and sucrose, whereas the SG-01 strain used glycogen. It was also found that the SG-02 strain used inositol as a carbon and energy source.

Manachini et al. (2000) reported that $G$. thermodenitrificans type strain DSM 465T grows well at 50 to $65^{\circ} \mathrm{C}$, with optimum $\mathrm{pH}$ values of 6 to 8 and in the presence of $3 \% \mathrm{NaCl}$. It is capable of reducing nitrates and nitrites to gas and of anaerobic gas production from nitrate. A common feature between SG-01 strain and DSM 465T strain was observed but specific growth rate of SG-01 strain was not as high as those for other Geobacillus sp. (>0.1). More than $70 \%$ of the isolates from the wood chip compost piles were classified as SG-01 strains based on the colony morphological characteristics, growth patterns, and $16 \mathrm{~S}$ rDNA sequence data. This suggests that Geobacillus thermodenitrificans is a common inhabitant of composts at $60^{\circ} \mathrm{C}$ under aerobic conditions, as earlier reported (Hatsu et al., 2002).

\section{Physiological characteristics of strain SG-01}

Optimal conditions for the growth of strain SG-01, including temperature, $\mathrm{pH}$, and $\mathrm{NaCl}$ concentration, were investigated. The specific SG-01 strain growth rates were 0.024 at $50^{\circ} \mathrm{C}, 0.027$ at $55^{\circ} \mathrm{C}, 0.026$ at $60^{\circ} \mathrm{C}$, and 0.025 at $65^{\circ} \mathrm{C}$. Poor growth was observed at $70^{\circ} \mathrm{C}$ and $37^{\circ} \mathrm{C}$. The optimal temperature for the growth of SG-01 was $55^{\circ} \mathrm{C}$. The optimum $\mathrm{pH}$ for SG-01 growth was 7.0. No growth was detected at $\mathrm{pH}$ values greater than 9.5. The strain grew in

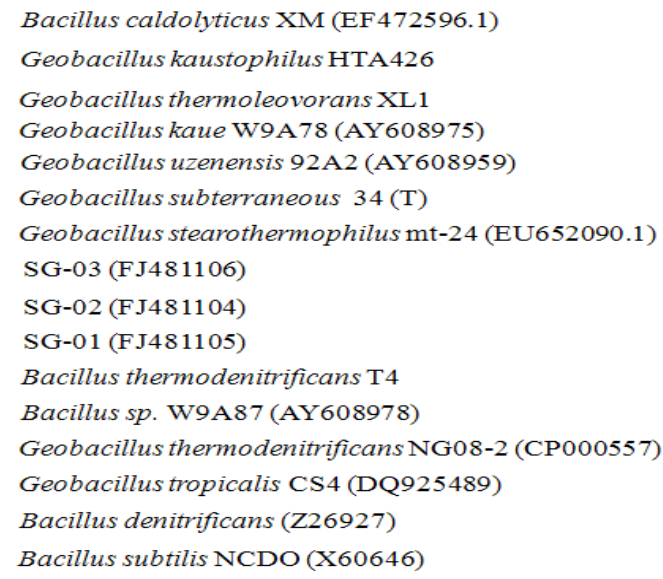

Figure 1. Neighbor-joining phylogenetic dendrogram, based on 16S rRNA gene sequences, indicating the positions of the strains studied among those of the other Geobacillus species. Bootstrap percentages (based on 1,000 samplings) are given at nodes. 
Table 1. Comparative characteristics of $G$ thermodenitrificans strains

\begin{tabular}{|c|c|c|c|c|c|c|}
\hline \multirow{2}{*}{ Characteristics } & \multicolumn{6}{|c|}{ Strains } \\
\hline & SG-01 & SG-02 & SG-03 & NG80-2 ${ }^{1}$ & DSM $465^{\mathrm{T} 2}$ & $\mathrm{HRO}^{3} 0^{3}$ \\
\hline Isolated origins & $\begin{array}{l}\text { Wood chip } \\
\text { compost }\end{array}$ & $\begin{array}{l}\text { Wood chip } \\
\text { compost }\end{array}$ & $\begin{array}{c}\text { Wood chip } \\
\text { compost }\end{array}$ & $\begin{array}{l}\text { Deep subsurface } \\
\text { oil }\end{array}$ & Sugar beet juice & Soil \\
\hline Optimum temperature $\left({ }^{\circ} \mathrm{C}\right)$ & 55 & & & 65 & $50-65$ & 50 \\
\hline Optimum pH & 7.0 & & & ND & $6-8$ & $6.5-7.5$ \\
\hline $\mathrm{NaCl}$ range $(\% \mathrm{w} / \mathrm{v})$ & $0-2$ & & & ND & $0-3$ & ND \\
\hline Nitrate reduction & Yes & & & Yes & Yes & ND \\
\hline \multicolumn{7}{|l|}{ Utilization of } \\
\hline L-Arabinose & - & + & + & + & & \\
\hline Galactose & - & - & - & + & & \\
\hline Fructose & + & + & - & + & & \\
\hline Inositol & - & + & - & + & & \\
\hline$\alpha$ Methyl-D-Glucoside & - & - & - & + & & \\
\hline N-Acetyl-Glucoseamine & - & - & - & + & & \\
\hline Salicin & + & + & + & - & & \\
\hline Melibiose & - & + & + & + & & \\
\hline Sucrose & - & + & + & + & & \\
\hline Raffinose & + & + & - & - & & \\
\hline Glycogen & + & - & - & - & & \\
\hline D-Turanose & - & - & - & + & & \\
\hline
\end{tabular}

ND = No data. ${ }^{1}$ Source: Feng et al. (2007). ${ }^{2}$ Source: Manachini et al. (2000). ${ }^{3}$ Source: Ezeji et al. (2005).

liquid media at $\mathrm{NaCl}$ concentrations of 0 to $3 \%$. The optimal $\mathrm{NaCl}$ concentration was $2.0 \%$, showing a specific growth rate of 0.025 . The specific growth rate of strain SG01 decreased at $\mathrm{NaCl}$ concentrations greater than $3.2 \%$.

\section{Nitrate and nitrite reduction}

The SG-01 growth curve was investigated using a jar fermenter at $55^{\circ} \mathrm{C}$ and $2.0 \% \mathrm{NaCl}$ for $48 \mathrm{~h}$. The maximum cell density of $2.87 \times 10^{8} \mathrm{CFU} / \mathrm{mL}$ of the strain SG-01 was reached in the LB broth at $12 \mathrm{~h}$ (Figure $2 \mathrm{~A}$ ). The $\mathrm{pH}$ was not changed during the fermentation period $(\mathrm{pH} 7.0)$. Nitrogen reduction by $\mathrm{SG}-01$ in nitrate-and-nitritecontaining LB broth was investigated. Nitrate was rapidly reduced within $12 \mathrm{~h}$, and approximately $91.8 \%$ of the nitrate was removed within $48 \mathrm{~h}$ (Figure 3A, 3B). The nitrate values in uninoculated controls did not decrease. These results suggest that strain SG-01 may reduce nitrate to nitrogen under aerobic conditions. Approximately $99 \%$ of the nitrite was reduced in $18 \mathrm{~h}$, and nitrites were no longer detected at $48 \mathrm{~h}$. Nitrite values of the inoculated controls did not decrease. The denitrifying ability of strain SG-01 was stronger than those of other microorganisms (Kariminiaae-Hamedaani et al., 2004). These results suggest that SG-01 could effectively remove nitrates and nitrites from wastewater.

\section{DISCUSSION}

We isolated microorganisms from composted wood chips with swine manure. One of the isolates, $G$. thermodenitrificans SG-01 was further characterized. The physiological characteristics of $G$. thermodenitrificans are summarized in Table 1. The SG-01 strain differs biochemically from NG80-2 and HRO10 with respect to optimal temperatures and $\mathrm{pH}$ values for growth.

Previous studies have shown that composting temperatures can significantly influence the rate of the composting process (Tiquia et al., 1997). Several researchers have found diverse bacteria in hot composts (Peters et al., 2000; Dees and Ghiorse, 2001) and an increase in respiratory activity at temperatures greater than $65^{\circ} \mathrm{C}$ (Beffa et al., 1996). The results of those studies provided evidence against the general understanding that bacterial activity and diversity in compost reduce dramatically at temperatures greater than $60^{\circ} \mathrm{C}$. A range of Geobacillus species can denitrify nitrates to nitrogen gas (Nazina et al., 2005), and reduction of nitrates and nitrites by cultures similar to strain SG-01 was observed in the present study. However, the SG-01 strain effectively removed approximately $90 \%$ of the nitrates and $100 \%$ of the nitrites in LB broth within $48 \mathrm{~h}$ of incubation. These results corroborate the findings of previous studies (Suthersan and Ganczarczyk, 1986; Turk and Mavinic, 1986).

Nitrate contamination in ground and surface water is an increasingly serious environmental problem; thus, biological denitrification is an essential process in the removal of nitrogen pollutants from aqueous ecosystems 


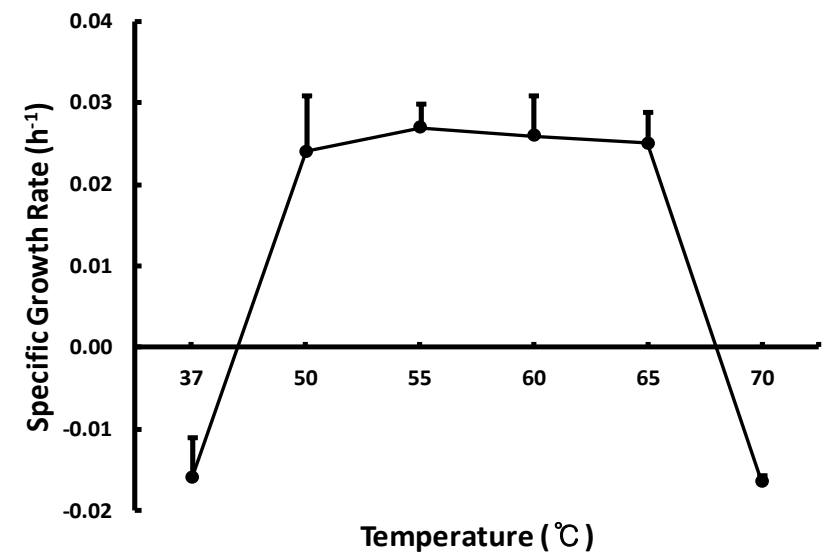

(A)

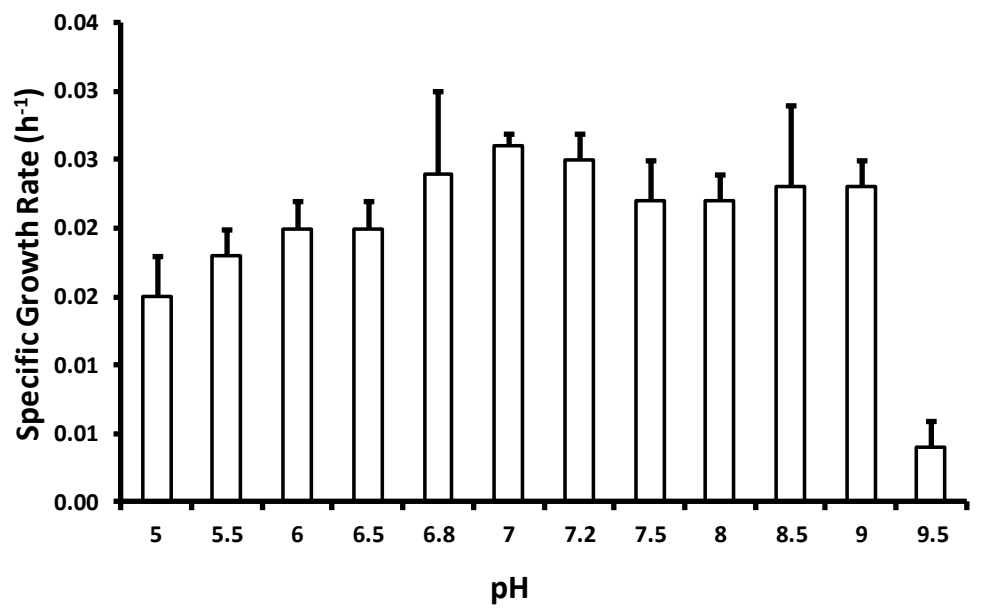

(B)

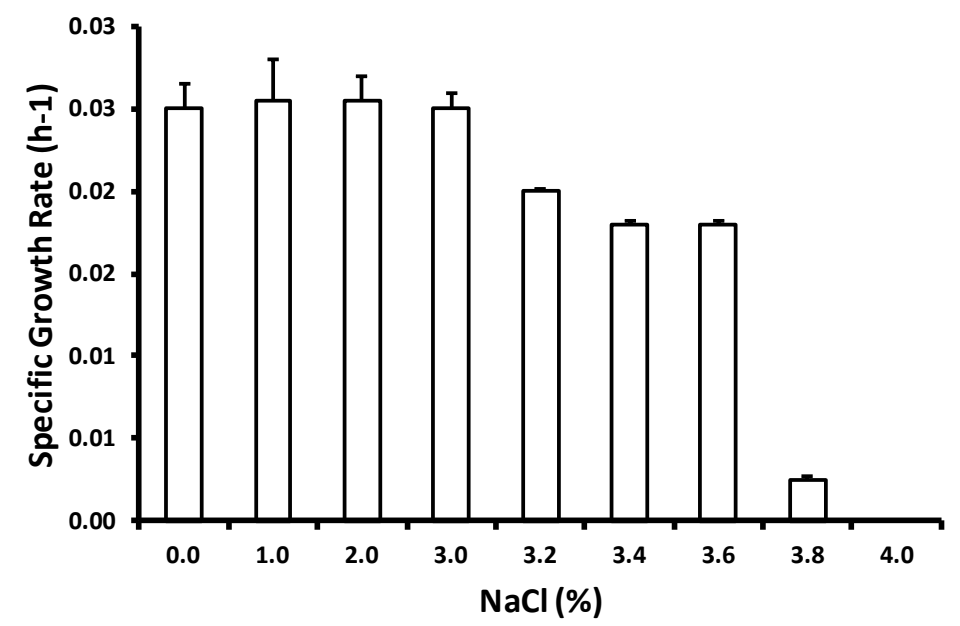

(C)

Figure 2. Optimal conditions for the specific growth rate of G. thermodenitrificans SG-01. Growth was determined in LB broth at various $(\mathrm{A})$ temperatures $\left({ }^{\circ} \mathrm{C}\right),(\mathrm{B}) \mathrm{pH}$, and $(\mathrm{C})$ salinity $(\% \mathrm{NaCl})$ after $24 \mathrm{~h}$. Values are expressed as the mean $(\mathrm{n}=3)$ and the error bars represents standard deviation $(\mathrm{SD})$.

(Van de Pas-Schoonen et al., 2005). Denitrification is a respectively, under oxygen-limited conditions (Philippot, respiratory process in which soluble nitrogen oxides, 2005a). Nitrite reductase is the key enzyme involved in nitrates, and nitrites are reduced to $\mathrm{NO}, \mathrm{N}_{2} \mathrm{O}$, and $\mathrm{N}_{2}$ gases, denitrification. It catalyzes the reduction of soluble nitrite 


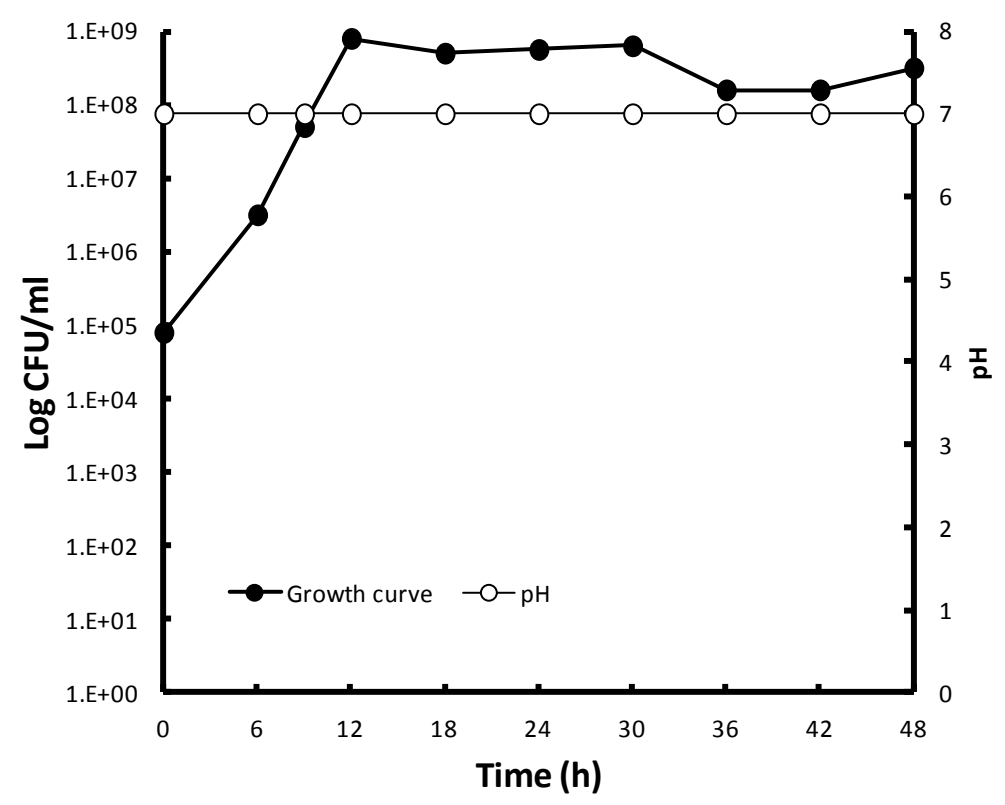

(A)

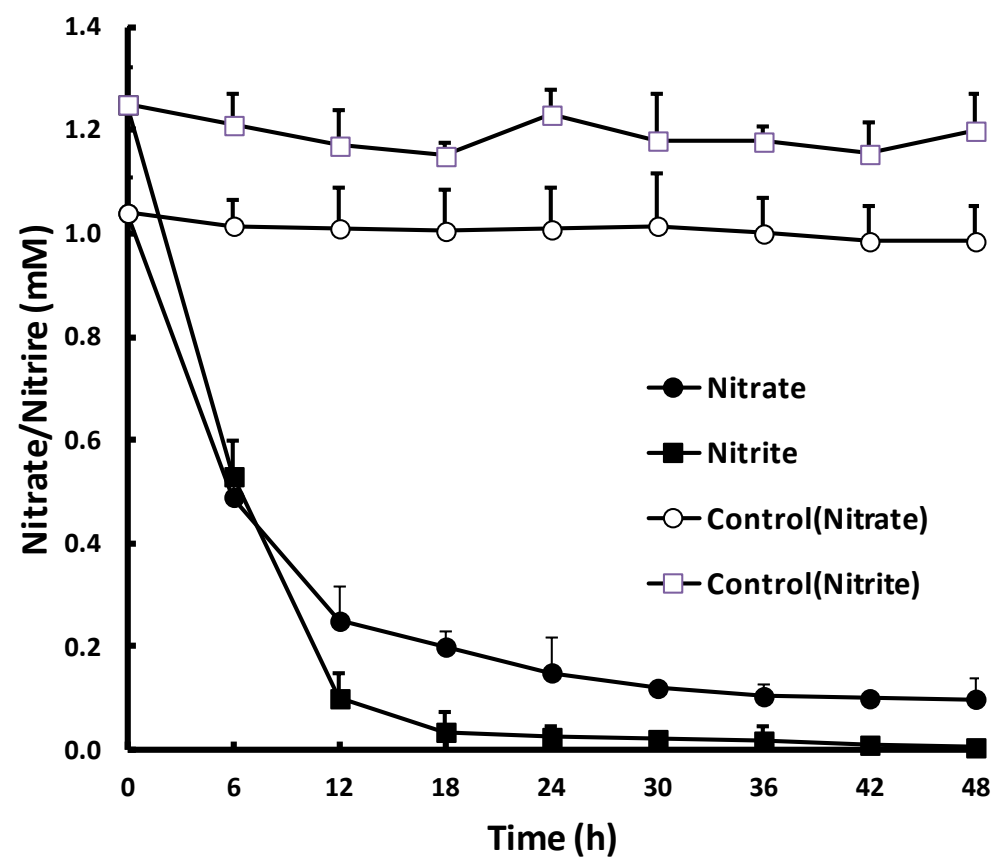

(B)

Figure 3. The growth curve (A) and the nitrate and nitrite reduction values (B) of $G$. thermodenitrificans SG-01 cultured in LB broth for $48 \mathrm{~h}$. The initial nitrate and nitrite concentrations were $1.18 \mathrm{mM}$ and $1.45 \mathrm{mM}$, respectively. Values are expressed as the mean $(\mathrm{n}=3)$ and the error bars represents standard deviation (SD).

into gas (Henry et al., 2004). Nitrite reductase can be found in other denitrifying or nitrite-reducing bacteria such as $P$. stutzeri and P. aeruginosa (Ward, 1995; Rinaldo et al., 2007). Livestock wastewater contains high levels of ammonia nitrogen, which causes nitrite buildup rather than normal nitrification. This inhibition of nitrification (Anthonisen et al., 1976) always depends on nonionic ammonia concentrations (free ammonia, $\mathrm{NH}_{3}$ ) and nonionic nitrogen salt concentrations (free nitrous acid, $\mathrm{HNO}_{2}$ ).

It should be noted that the denitrification experiments in the present study were only performed under laboratory conditions, and future research should be more reflective of actual environmental conditions. Nonetheless, our results suggest that G. thermodenitrificans SG-01 may be useful for the effective removal of nitrates and nitrites from wastewater, particularly liquid swine manure. 


\section{ACKNOWLEDGEMENTS}

This research was partially supported by the GRRC project of the Gyeonggi Provincial Government, Republic of Korea and carried out with the support of "Cooperative Research Program for Agriculture Science \& Technology Development (Project No. PJ90711005)" Rural Development Administration, Republic of Korea.

\section{REFERENCES}

Altschul, S. F., T. L. Madden, A. A. Schaffer, J. Zhang, Z. Zhang, W. Miller, and D. J. Lipman. 1997. Gapped BLAST and PSIBLAST: a new generation of protein database search programs. Nucl. Acids Res. 25: 3389-3402.

APHA (American Public Health Association). 1989. Standard methods for the examination of water and wastewater, 17th ed. American Public Health Association, Washington, DC, pp. 4.123, 4.129.

Anthonisen, A. C., R. C. Loehr, T. B. Prakasam and E. G. Srinath. 1976. Inhibition of nitrification by ammonia and nitrous acid. J. Water Pollut. Control Fed. 48:835-852.

Beffa, T., M. Blanc, P. F. Lyon, G. Vogt, M. Marchiani, J. L. Fischer, and M. Aragno. 1996. Isolation of Thermus strains from hot composts (60 to 80 degrees C). Appl. Environ. Microbiol. 62:1723-1727.

Cheneby, D., S. Perez, C. Devroe, S. Hallet, Y. Couton, F. Bizouard, G. Iuretig, J. C. Germon, and L. Philippot. 2004. Denitrifying bacteria in bulk and maize-rhizospheric soil: diversity and $\mathrm{N}_{2} 0$-reducing ability. Can. J. Microbiol. 50:469474.

Choi, E., Y. Yu, M. Cui, Z. Yun, and K. Min. 2008. Effect of biologically mediated $\mathrm{pH}$ change on phosphorus removal in BNR system for piggery waste treatment. J. Environ. Sci. Health. Part A: Tox Hazard. Subst. Environ. Eng. 43:154-160.

Clause, D. and R. C. W. Berkeley. 1986. The genus Bacillus. In: Bergey's Manual of Systematic Bacteriology (Ed. P. H. A. Sneath, N. S. Mair, M. E. Sharpe, and J. G. Holt). Baltimore, USA: Williams \& Wilkins Co. pp. 1105-1139.

Dees, P. M. and W. C. Ghiorse. 2001. Microbial diversity in hot synthetic compost as revealed by PCR-amplified rRNA sequences from cultivated isolates and extracted DNA. FEMS Microbiol. Ecol. 35:207-216.

Deflaun, M. F., J. K. Fredrickson, H. Dong, S. M. Pfiffner, T. C. Onstott, D. L. Balkwill, S. H. Streger, E. Stackebrandt, S. Knoessen, and E. Van, Heerden. 2007. Isolation and characterization of a Geobacillus thermoleovorans strain from an ultra-deep South African gold mine. Syst. Appl. Microbiol. 30:152-164.

De, Guardia, A., C. Petiot, D. Rogeau, and C. Druilhe. 2008. Influence of aeration rate on nitrogen dynamics during composting. Waste Manag. 28:575-587.

Ezeji, T. C., A. Wolf, and H. Bahl. 2005. Isolation, characterization, and identification of Geobacillus thermodenitrificans HRO10, an $\alpha$-amylase and $\alpha$-glucosidase producing thermophile. Can. J. Microbiol. 51:685-693.

Felsenstein, J. 1993. PHYLIP (phylogeny interference package), version 3.5c. Distributed by the author. Department of Genome
Science, University of Washington, Seattle, USA.

Feng, L., W. Wang, J. Cheng, Y. Ren, G. Zhao, C. Gao, Y. Tang, X. Liu, W. Han, X. Peng, R. Liu, and L. Wang. 2007. Genome and proteome of long-chain alkane degrading Geobacillus thermodenitrificans NG80-2 isolated from a deep-subsurface oil reservoir. Proc. Natl. Acad. Sci. USA 104:5602-5607.

Galkiewicz, J. P. and C. A. Kellogg. 2008. Cross-kingdom amplification using bacteria-specific primers: complications for studies of coral microbial ecology. Appl. Environ. Microbiol. 74:7828-31.

Gilbert, Y., Y. Le Bihan, G. Aubry, M. Veillette, C. Duchaine, and P. Lessard. 2008. Microbiological and molecular characterization of denitrification in biofilters treating pig manure. Bioresour. Technol. 99:4495-4502.

Green, L. C., D. A. Wagner, J. Glogowski, P. L. Skipper, J. S. Wishnok, and S. R. Tannenbaum. 1982. Analysis of nitrate, nitrite, and $\left[{ }^{15} \mathrm{~N}\right]$ nitrate in biological fluids. Anal. Biochem. 126:131-138

Hatsu, M., J. Ohta, and K. Takamizawa. 2002. Monitoring of Bacillus thermodenitrificans OHT-1 in compost by whole cell hybridization. Can. J. Microbiol. 48:848-852.

Henry, S., E. Baudoin, J. C. Lopez-Gutierrez, F. Martin-Laurent, A. Brauman, and L. Philippot. 2004. Quantification of denitrifying bacteria in soils by nirK gene targeted real-time PCR. J. Microbiol. Methods 59:327-335.

Horiuchi, J. I., K. Ebie, K. Tada, M. Kobayashi, and T. Kanno. 2003. Simplified method for estimation of microbial activity in compost by ATP analysis. Bioresour. Technol. 86:95-98. DOI: http://dx.doi.org/10.1016/S0960-8524(02)00108-6.

Kariminiaae-Hamedaani, H. R., K. Kanda, and F. Kato. 2004. Denitrification activity of the bacterium Pseudomonas $s p$. ASM-2-3 isolated from the Ariake Sea tideland. J. Biosci. Bioeng. 97:39-44.

Kimura, M. 1983. The neutral theory of molecular evolution. Cambridge University Press, Cambridge, UK.

McGowin, A. E., K. K. Adom, and A. K. Obubuafo. 2001. Screening of compost for PAHs and pesticides using static subcritical water extraction. Chemosphere 45:857-864. DOI: http://dx.doi.org/10.1016/S0045-6535(01)00043-1.

Manachini, P. L., D. Mora, G. Nicastro, C. Parini, E. Stackebrandt, R. Pukall, and M. G. Fortina. 2000. Bacillus thermodenitrificans sp. nov., nom. rev. Int. J. Syst. Evol. Microbiol. 50:1331-1337.

Nazina, T. N., D. S. Sokolova, A. A. Grigoryan, N. M. Shestakova, E. M. Mikhailova, A. B. Poltarius, T. P. Tourova, A. M. Lysenko, G. A. Osipov, and S. S. Belyaev. 2005. Geobacillus jurassicus sp. nov., a new thermophilic bacterium isolated from a high temperature petroleum reservoir, and the validation of the Geobacillus species. Syst. Appl. Micribiol. 28:43-53

Peters, S., S. Koschinsky, F. Schwieger, and C. C. Tebbe. 2000. Succession of microbial communities during hot composting as detected by PCR-single-strand-conformation polymorphismbased genetic profiles of small-subunit rRNA genes. Appl. Environ. Microbiol. 66:930-936.

Philippot, L. 2005a. Denitrification in pathogenic bacteria: for better or worst? Trends Microbiol. 13:191-192.

Philippot, L. 2005b. Tracking nitrate reducers and denitrifiers in the environment. Biochem. Soc .Trans. 33:200-204. 
Rinaldo, S., A. Arcovito, M. Brunori, and F. Cutruzzola. 2007. Fast dissociation of nitric oxide from ferrous Pseudomonas aeruginosa $\mathrm{cd}_{1}$ nitrite reductase: A novel outlook on the catalytic mechanism. J. Biol. Chem. 282:14761-14767.

Saitou, N. and M. Nei. 1987. The neighboring-joining method: a new method for reconstructing phylogenetic trees. Mol. Biol. Evol. 4:406-425.

Sogin, M. L. 1990. Amplification of ribosomal RNA genes for molecular evolution studies. In: PCR Protocols: A Guide to Methods and Applications (Ed. M. A. Innis, D. H. Gelfand, J. J. Sninsky, T. J. White). London, United Kingdom: Academic Press, Inc. pp. 307-314.

Strom, P. F. 1985. Identification of thermophilic bacteria in solidwaste composting. Appl. Environ. Microbiol. 50:906-913.

Suler, D. J. and M. S. Finstein. 1977. Effect of temperature, aeration, and moisture on $\mathrm{CO}_{2}$ formation in bench-scale, continuously thermophilic composting of solid waste. Appl. Environ. Microbiol. 33:345-350.

Suthersan, S. and J. J. Ganczarczyk. 1986. Inhibition of nitrite oxidation during nitrification: Some observations. Water. Pollut. Res. J. Can. 21:257-226.

Thompson, J. D., D. G. Higgins, and T. J. Gibson. 1994. Clustal $\mathrm{W}$ : improving the sensitivity of progressive multiple sequence alignment through sequence weighting, position-specific gap penalties and weight matrix choice. Nucl. Acids Res. 22:46734680.

Tiquia, S. M., N. F. Y. Tam, and I. J. Hodgkiss. 1997. Composting of spent pig litter at different seasonal temperatures in subtropical climate. Environ. Pollut. 98:97-104.
Tiquia, S. M. and N. F. Y. Tam. 2000. Fate of nitrogen during composting of chicken litter. Environ. Pollut. 110:535-541. DOI: http://dx.doi.org/10.1016/S0269-7491(99)00319-X.

Turk, O. and D. S. Mavinic. 1986. Preliminary assessment of a shortcut in nitrogen removal from wastewater. Can. J. Civ. Eng. 13:600-605.

Van, De, Pas-Schoonen, K. T., S. Schalk-Otte, S. Haaijer, M. Schmid, H. Op Den, Camp, M. Strous, J. Gijs Kuenen, and M. S. M. Jetten. 2005. Complete conversion of nitrate into dinitrogen gas in co-cultures of denitrifying bacteria. Biochem. Soc. Trans. 33:205-209.

Wang, C. M., C. L. Shyu, S. P. HO, and S. H. Chiou. 2007. Species diversity and substrate utilization patterns of thermophilic bacterial communities in hot aerobic poultry and cattle manure composts. Microb. Ecol. 54:1-9.

Ward, B. B. 1995. Diversity of culturable denitrifying bacteria. Limits of rDNA RFLP analysis and probes for the functional gene, nitrite reductase. Arch. Microbiol. 163:167-175.

Zhou, Q., S. Takenada, S. Murakami, P. Seesuriyachan, A. Kuntiya, and K. Aoki. 2007. Screening and characterization of bacteria that can utilize ammonium and nitrate ions simultaneously under controlled cultural conditions. J. Biosci. Bioeng. 103: 185-191.

Zoes, V., H. Dinel, T. Pare, and A. Jaouich. 2001. Growth substrates made from duck excreta enriched wood shavings and source-separated municipal solid waste compost and separates: physical and chemical characteristics. Bioresour. Technol. 78:21-30. 